\title{
Impact of Land Use/Land Cover Change on Reservoir Sedimentation: The Case of Ribb Dam Reservoir, Lake Tana Sub Basin, Ethiopia
}

\author{
Asimamaw Nigusie Asitatikie \\ Department of Hydraulic and Water Resources Engineering, \\ Debre Tabor University, Debre Tabor, Ethiopia
}

\begin{abstract}
ACKNOWLEDGEMENTS
I would like to thank the following organizations for providing free charge of data: Ethiopian National Meteorology Agency, Ministry of Water Irrigation and Energy and Tana Sub-Basin Organizations.Very special thanks to, Dr. Mekete Dessie, for his precious and valuable help, encouragement and decisive comment from the inception to the completion of this research work. His constructive idea and follow ups helped me to take this research in the right direction. He also provide the sediment rating curve what he has developed with his collaborative before in my watershed.I would also like to express my sincere thanks to my wonderful family, for their ultimate support throughout my life.
\end{abstract}

\begin{abstract}
The land and water resources of the Lake Tana Sub Basin basin is in danger due to soil erosion, sediment transport, land degradation and storage capacity reduction. There is a need for sediment transport research of this basin that can improve catchment's management programs.

This study assesses the impact of land use and land cover change effects on reservoir sedimentation using SWAT model in Upper Ribb watershed. The land use and land cover change analyses for three different years of 1973, 1995 and 2016 were performed using ERDAS Imagine 2014 which was in turn used for estimation of sediment yield. In this study the bush/shrub land were changed to grazing and cultivated land. An increase of cultivated land by $29.947 \%$ over 43 years $(1973$ - 2016) period resulted in an increase of sediment yield by 343.25 $\mathrm{t} / \mathrm{km}^{2} /$ year respectively. Model calibration and validation for sediment yield were done at Abo Bahir. The performance of the model was also checked at this station. Both the monthly calibration and validation results showed good match between measured and simulated sediment yield data with the coefficient of determination $\left(\mathrm{R}^{2}\right)$ of 0.857 , Nash-Sutcliffe efficiency (NSE) 0.832 for the calibration, and $R^{2}$ of 0.834 and NSE of 0.796 of the validation period.

Spatial sediment distribution was done using the calibrated and validated sediment yield results of 2016 land use. High potential source areas were found at north-eastern part of the watershed which was a combined result of highly cultivated land, steep slope and erosive soil (Eutric Leptosols). Therefore, these critical sub- watersheds should preserve from further exposing of soil erosion through either forest resource development or uncultivated the steeply slope areas. And also the increasing/expanding bushes/shrub land should also be encouraged in the watershed first by applying for those most erosion prone sub watersheds.
\end{abstract}

Keywords: Upper Ribb watershed, SWAT, sediment yield, spatial sediment distribution.

DOI: $10.7176 / \mathrm{CER} / 12-5-01$

Publication date:May $31^{\text {st }} 2020$

\section{INTRODUCTION}

The total environmental effects such as change in vegetation cover, soil characteristics, flora and fauna population and hydrological cycle have been strongly influenced by the conversion of land and forest resources (Hurni et al., 2010). Land use/cover dynamics and subsequent conversion lead to loss of biodiversity, deterioration in the physical and chemical properties of soil which causes degradation of the land (Emadodin et al., 2009). Land use/cover changes are highly pronounced in the developing countries that are characterized by agriculture based economies and rapidly increasing human populations.

Population growth causes degradation of resources particularly forests that rely on the available land. This increases the run off volume by decreasing infiltration as well as increase the amount of sediment or erosion content that is transported by the run off in the catchment.

An understanding of the quantity of sediment deposition in a reservoir is necessary for effective reservoir and basin management. Sedimentation affects both the useful life of a reservoir for such important purposes as water supply and flood control as well as its aesthetic quality.

Land use planning and management are closely related to the sustainability of water resources as changes of land use are linked with amount of water through relevant hydrological processes (Guo et al., 2008). To maintain water sustainability, effective methods and mechanisms should be used. Nowadays, the hydrological models are 
good to represent the hydrological characteristics (Surur, 2010).

There are two basic advantages using hydrological models instead of relying only on collected data (Droogers and Kite, 2001). In the first place models can be used to understand the processes that are difficult to measure due to the complexity of temporal and/or spatial scale. Secondly, a model can be used to study the effect of changes in land cover, water management or climate.

Poor land use practices and improper management systems have played a significant role in causing high soil erosion rates, sediment transport and loss of agricultural nutrients. So far limited measures have been taken to combat the problems.

The knowledge how land use/cover change influence soil erosion will enable local governments and policy makers to formulate and implement effective and appropriate response strategies to minimize the undesirable effects of future land use/cover change or modifications.

The key intention of this study aims application of soil and water assessment tool (SWAT) for the assessment of land use and cover change effects on sediment yield of the Upper Ribb watershed. The main objective of this study was to evaluate the amount of sediment yield under different land use/cover changes of the Upper Ribb River catchment. In addition this study was also done to characterize the watershed in terms of spatial variability of sediment and physical catchment characteristics under the recent land use

\section{Description of study area}

Upper Ribb watershed is one of the major tributaries of the Lake Tana basin, Ethiopia. The Upper Ribb watershed is located in South Gonder Zone of the Amhara National Regional State of Ethiopia.

The study area is located with a geographical coordinates of $12^{\circ} 35^{\prime}$ to $13^{\circ} 54^{\prime}$ north and $34^{0} 59^{\prime}$ to $41^{\circ} 25^{\prime}$ east latitude and longitude respectively. The Upper Ribb river originates from high (Guna) mountain at an elevation of 4090 m.a.s.l and drains to the Ribb Dam Reservoir in the northeast part of Lake Tana. The catchment area of Upper Ribb watershed at the Ribb dam outlet is $678.15 \mathrm{~km}^{2}$.

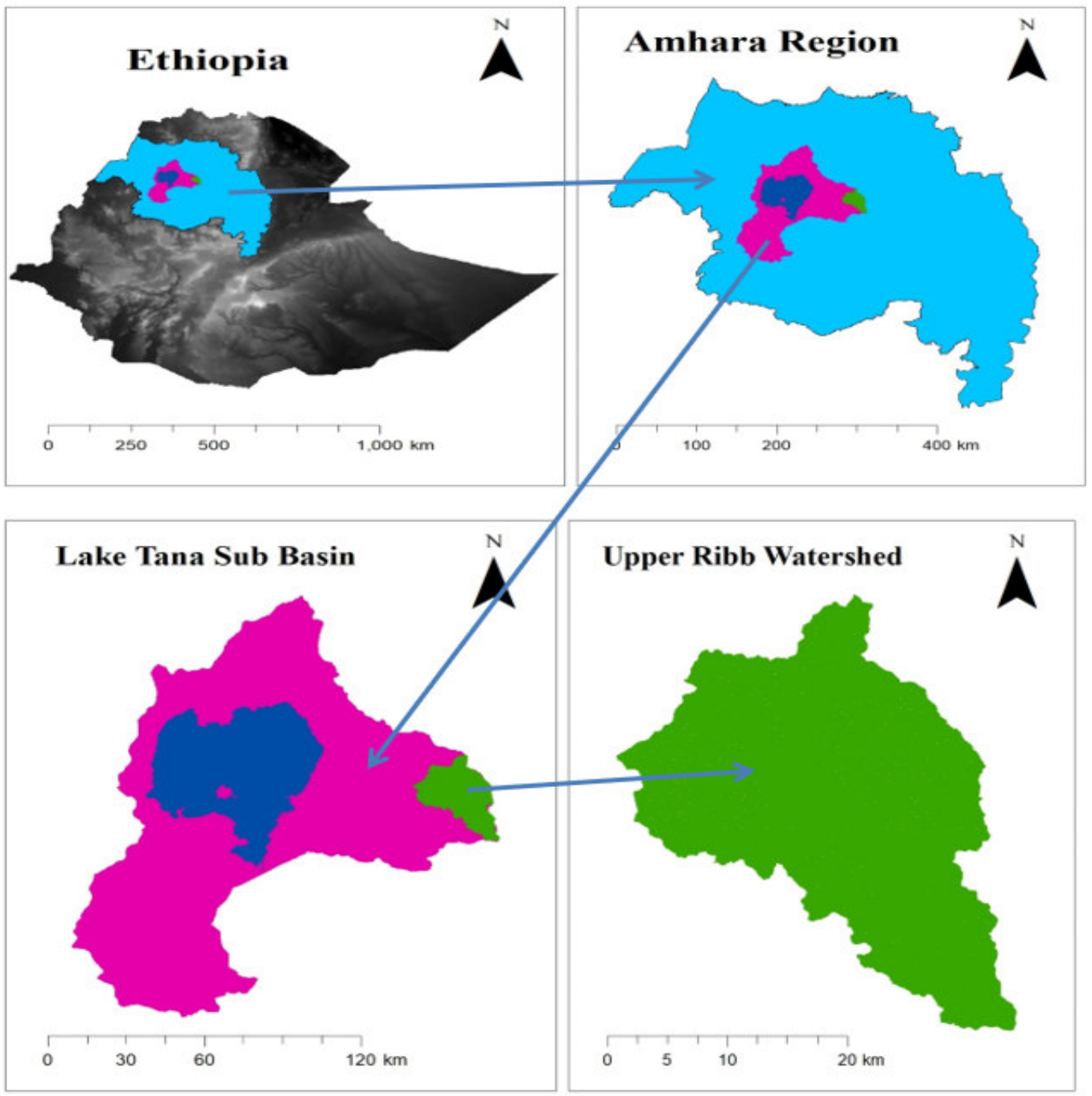

Figure 2. 1 Location of Upper Ribb Watershed 


\section{Methods}

The general methodology followed for this study consist the following major activities.

Preparation of the different types of land cover of the study area for the three years 1973, 1995 and 2016 and acquisition of data like DEM, daily sediment data, daily rainfall, maximum and minimum temperature, sunshine hours and wind speed from different sources.

After collection of necessary data, processing the hydro - meteorological data to analyze the results from data processing, and then converting the image and hydro- meteorological data processing to reflect and to match model parameters. Finally the results of the modeling with respect the land cover change were analyzed.

Generally, the methodology for this study can be described by the following flow Chart.

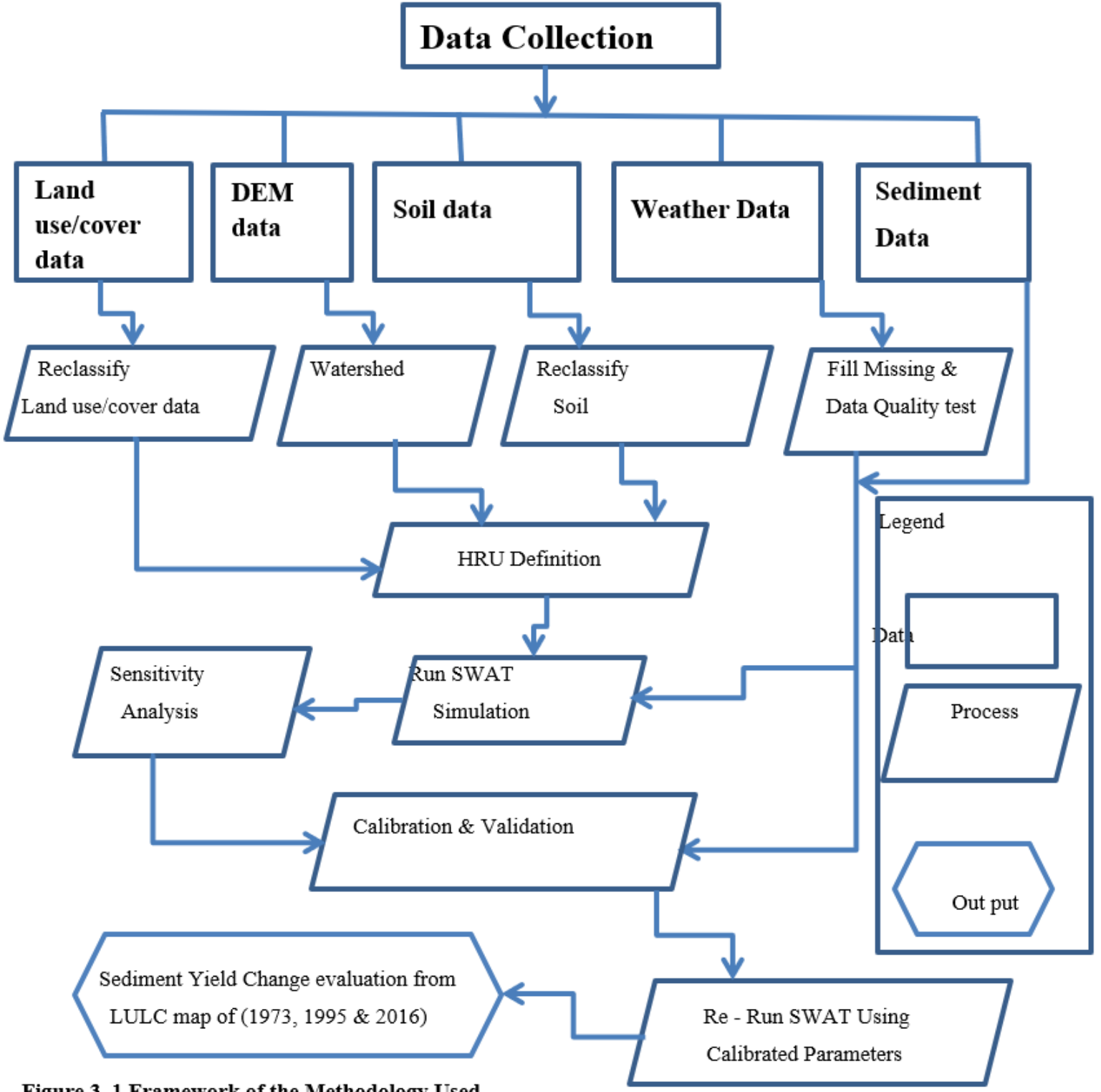

Figure 3. 1 Framework of the Methodology Used

\subsection{Data Collection and Analysis}

\subsubsection{Land use land cover data}

Land use and land cover (LULC) data which is very essential for SWAT input for determining the watershed characteristics, and also used for comparison of impacts on sediment yield of the catchment was acquired from http://earthexplorer.usgs.gov/. The satellite images used for this study were taken in the dry season due to the satellite images were in good quality (free of cloud cover), easy for identification of cultivated lands and grazing lands. The process of detecting LULC after downloading from this site was through image processing and classification of images.

Based on the priori knowledge of the study area and additional information from previous research in the study area (Garede and Minale, 2014) and (Ephrem , 2011), seven different types of land use and land cover has 
been identified for the Upper Ribb Catchment. These are described as follows:

Cultivated land; Areas used for crop cultivation, both annually and perennially. It is the area with standing crop, tree crops, and crop lands where the crops were harvested.

Bush and Shrub land; Areas with bushes, shrubs and small trees, with little wood and mixed with some grasses. It includes plantation trees and scrub vegetation at the fringes of forest cover and areas dominated by scattered trees.

Grazing land; Areas covered with grass used for grazing, as well as bare lands that have little grass or no grass cover. It also includes other small sized plant species.

Water bodies; Areas with surface water in the form of ponds, reservoirs, lakes, streams, rivers and its main tributaries.

Forest land; Land covered with dense trees which are mainly ever green forest land

Urban and Settlement Area; Areas with low density to high density residential. It comprises both dispersed rural and urban settlement areas.

Woody Savanna Land; Areas cover with wood mixed with higher grass cover including seasonal as well as permanent wetlands.

In this particular study the image was classified based on the pixel based Maximum Likelihood supervised classification method. This is due to the fact that unlike other classifiers it considers the spectral variation with in each category and the overlap that may occur among different classes (Campbell and Mortenson, 1989).

Accuracy assessment must be done to determine how well the classification process accomplished the task. The most widely used classification accuracy is in the form of error matrix which can be used to derive a series of descriptive and analytical statistics (Manandhar et al., 2009b). The columns of the matrix depict the number of pixels per class for the reference data, and the rows show the number of pixels per class for the classified image. From this error matrix, a number of accuracy measures such as overall accuracy, user's accuracy, producer's accuracy and Kappa statistics are determined. The overall accuracy is used to indicate the accuracy of the whole classification (i.e. number of correctly classified pixels divided by the total number of pixels in the error matrix), whereas the other two measures indicate the accuracy of individual classes. User's accuracy is regarded as the probability that a pixel classified on the map actually represents that class on the ground or reference data, whereas product's accuracy represents the probability that a pixel on reference data has been correctly classified (Manandhar et al., 2009a). Kappa statics is a type of technique used in accuracy assessment. It expresses the agreement between two categorical data sets.

In this study, accuracy assessment was performed using the available and the Google Earth Image together with previous knowledge of the area which used as reference data to generate testing data set by generating certain random testing points. A total of 200 testing sample points were selected randomly for the recent year 2016 and accuracy assessment was done.

\subsubsection{Sediment yield data}

Daily sediment data is required for SWAT simulation result calibration and validation. The daily sediment data was collected from Ministry of Water, Irrigation and Electricity of Ethiopia (MoWIE) in concentration basis or in suspended sediment rating equation, which was developed by BCEOM (1999). However, these suspended sediment concentrations or developed sediment rating equation was not used for the calibration and validation of sediment yield in this study. This was mainly due to the reason that the temporal distribution of the SSC data from BCEOM (1999) is uneven and sampling took place during the rainy seasons when sediment concentrations are high (Zimale et al., 2016). Besides, their SY prediction is based on mean monthly runoff discharge which is a rough temporal resolution leading to overestimation. Thus, to accommodate the above coarse sediment concentration measurements seasonal variability of sediment estimation was considered for this study. The monthly observed sediment yield was developed from a simple linear regression sediment rating curve at Abo Bahir $\left(1166 \mathrm{~km}^{2}\right)$. At this site suspended sediment concentration was measured and rating curves were developed from 2012 to 2013 (Lemma et al., 2017). They develop those curves by subdivided the datasets into five periods (i.e. October- April, May - June, July, August and September) based on changes in rainfall, soil moisture and land-cover conditions as follows.

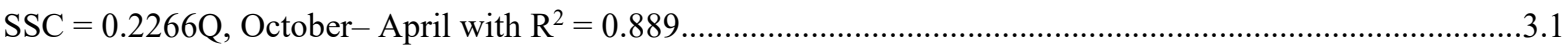

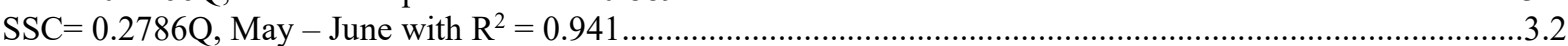

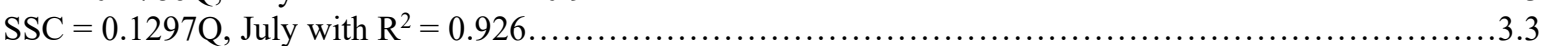

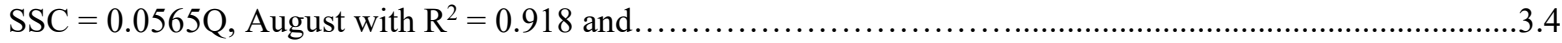

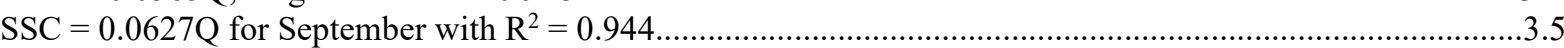

Where; SSC $=$ Suspended sediment concentration $(\mathrm{g} / \mathrm{l})$

$\mathrm{Q}=$ Discharge $\left(\mathrm{m}^{3} / \mathrm{s}\right)$

Based on the above rating equations the monthly suspended sediment loads were estimated. But, the stream flow was needed at this ungauged site to calculate Suspended sediment concentration. Therefore, at this ungauged site (Abo Bahir) the stream flow was estimated by extrapolating the flow at Upper Ribb gauging station using 
catchment area ratio. This is due to the reason that the two sites are in one catchment (i.e they have comparable gauged catchments and have the same climate and catchment conditions). A relation Q at Abo Bahir was (area of

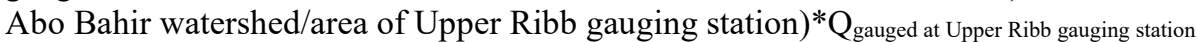
were developed for estimating the flow at the Abo Bahir; which was

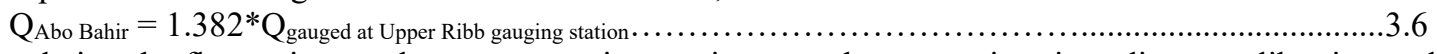

Extrapolating the flow using catchment area ratio may increase the uncertainty in sediment calibration and validation. However, due to insufficient sediment concentrations, uneven temporal suspended sediment concentrations and sampling took place during the rainy seasons when sediment concentrations are high, it was preferred to extrapolate and use the developed curve at Abo Bahir.

\subsection{SWAT Model Setup}

\subsubsection{Watershed Delineation}

The watershed and sub watershed delineation process in Arc SWAT consists of five major steps, DEM setup, stream definition, outlet and inlet definition, watershed outlets selection and definition and calculation of sub basin parameters(Asres and Awulachew, 2010). After the DEM setup was completed and the mask data was provided on the DEM, the model automatically calculates the flow direction and flow accumulation. Consequently, stream networks, sub basin outlet, whole and sub watersheds and topographic parameters were calculated using the respective tools. The threshold based stream definition option in the stream definition was used to define the minimum size of the sub-basins. As suggested by the Arc SWAT interface (the smaller the specified number of hectares, the more detailed the drainage network delineated by the interface) a minimum threshold area in hectares were selected. This was used to show the detail soil erosion hot spot sub watersheds in the area. The watershed was sub-divided into 27 sub-watersheds using the default (minimum) threshold area which was 1356.29ha.

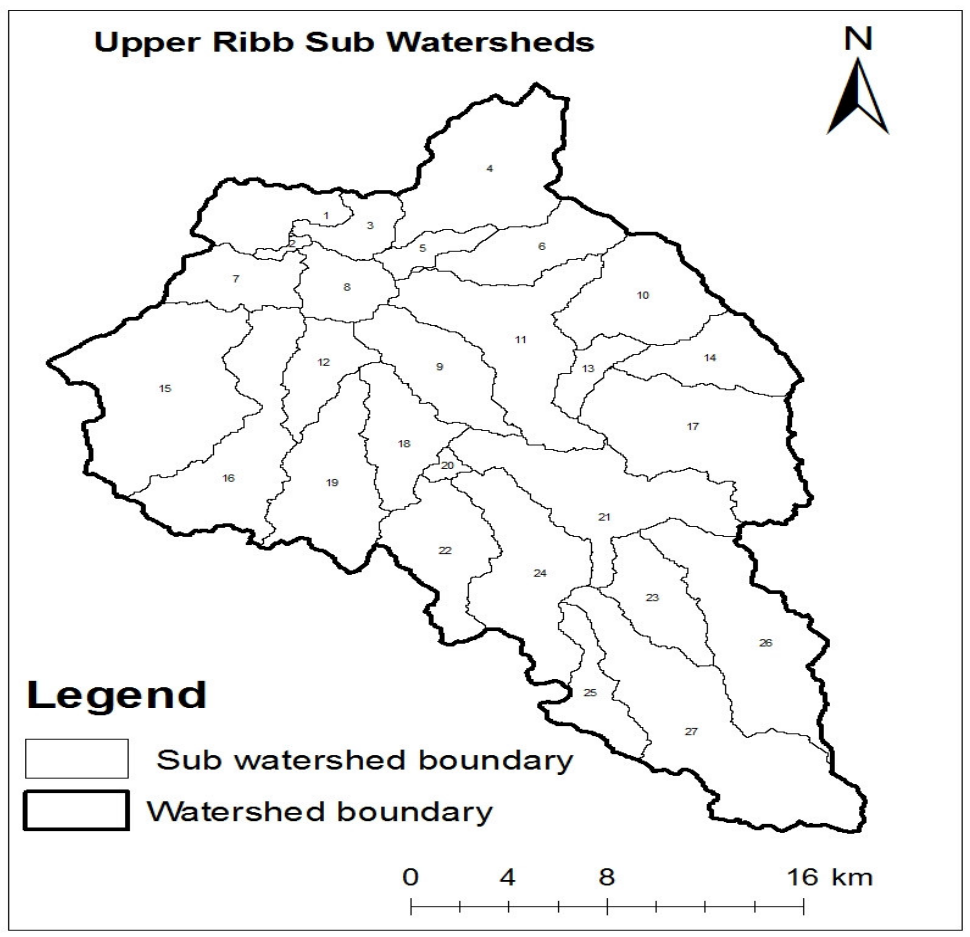

Figure 3. 2 Sub watershed map of Upper Ribb Watershed

\subsubsection{Hydrological Response Units (HRUs) Analysis}

The land use/cover, slop and soil map were imported into the interface and reclassified. The SWAT database has only values of hydrological property parameters of the most common type of land use/cover classes. But, some of the land use/cover classes and their parametric values did not exist in SWAT default data base. Therefore, it was necessary to replace these classes with land use/cover classes of the SWAT database which have similar hydrological properties (Table 3.1). The soil map of the study area was reclassified according to Arc SWAT requirements.

Slope classification was carried out using a multiple slope option into five number of slope classes. Next, all the reclassified three maps were overlaid. Then, the sub basins were divided into Hydrologic Response Units (HRUs) by assigning the threshold values of land use/cover, soil and slope percentage. When multiple HRUs was assigned to each sub basin the thresh hold level should be defined in which the user can specify sensitivities for land use/cover, soil and slope data that will be used to determine the number and kind of HRUs in each watershed. 
According to (Setegn et al., 2008), HRU definition with multiple options that account for $10 \%$ land use, $20 \%$ soil and 10\% slope threshold combination gives a better estimation of runoff and sediment components. Therefore, for this study, HRU definition with multiple options that accounts for $10 \%$ land use, $20 \%$ soil and $10 \%$ slope threshold combination was used. Hence, there were created 76, 81 and 79 HRUs for land uses of 1973, 1995 and 2016 respectively.

Table 3. 1 The reclassified land use and land cover classes for SWAT database

\begin{tabular}{|c|c|c|c|c|}
\hline \multirow[t]{2}{*}{ S.No } & \multirow[t]{2}{*}{ Land use } & \multicolumn{3}{|c|}{ SWAT Code } \\
\hline & & 1973 & 1995 & 2016 \\
\hline 1 & Cultivated Land & DWHT & DWHT & DWHT \\
\hline 2 & Grazing Land & PAST & PAST & PAST \\
\hline 3 & Bush and Shrub Land & RNGB & RNGB & RNGB \\
\hline 4 & Forest Cover & FRST & FRST & FRST \\
\hline 5 & Urban and Settlement Area & URLD & URML & URMD \\
\hline 6 & Water Body & WATR & WATR & WATR \\
\hline 7 & Woody Savanna Land & & & RNGE \\
\hline
\end{tabular}

\subsection{Sensitivity Analysis, Calibration and Validation of the Model}

\subsubsection{Sensitivity Analysis}

The results from SWAT simulation cannot be directly used for further analysis but instead used for further analysis to sufficiently predict the constituent sediment yield should be evaluated through sensitivity analysis, calibration and validation of the model (White and Chaubey, 2005).

When a SWAT simulation was taken place there was a discrepancy between measured data and simulated results. So, to minimize this discrepancy, it was necessary to determine the parameters which are affecting the results and the extent of variation. Hence, to check this, sensitivity analysis is one of SWAT model tool to show the rank and the mean relative sensitivity (MRS) of parameters identification and this step ordered to analysis. Sensitivity analysis helps to determine the sensitivity of parameters by comparing the output variance due to input variability. It also facilitates selecting important and influential parameters for a model calibration by indicating the parameters that shows higher sensitivity to the output due to the input variability. Therefore, the number parameters that can be involved for calibration will be less in number and influential. It also evaluates the model capacity and helps to understand the behavior of the system being modeled.

Sensitivity analysis was performed to determine the influence a set of parameters had on predicting total sediment yield. It was performed on around six sediment parameters.

By applying default lower and upper boundary parameter values, the parameters were tested for sensitivity analysis for the simulation of sediment yield. The sensitivity analyses were run for sediment parameters using Abo Bahir Measured sediment. In the analysis, the sensitive parameters of the sediment yield of the watershed were identified. The parameters, which resulted from the analysis, were ranked with their category of classification according to the magnitudes of the mean relative sensitivity (MRS) values (Lenhart et al., 2002).

Table 3. 4 SWAT Parameters Sensitivity class per (Lenhart et al., 2002)

\begin{tabular}{|l|l|l|}
\hline Sensitivity Class & MRS & Sensitivity Category \\
\hline I & $0.00 \leq \mathrm{MRS}<0.05$ & Small to negligible \\
\hline II & $0.05 \leq \mathrm{MRS}<0.20$ & Medium \\
\hline III & $0.2 \leq \mathrm{MRS}<1$ & High \\
\hline IV & MRS $>1$ & Very high \\
\hline
\end{tabular}

Therefore, based on the above classification parameters producing very high, high and medium MRS values gave high and prior attention for calibration process.

\subsubsection{Model Calibration}

Model calibration is a means of adjusting or fine tuning model parameters to match with the observed data as much as possible, with limited range of deviation accepted (Neitsch et al., 2002). It is the procedure of adjustment of parameter values of a model to reproduce the response of reality within the range of accuracy specified in the performance criteria (Neitsch et al., 2002). Parameters for adjustment are selected from those identified by sensitivity analysis. The process of adjustment can be done manually or automatic methods. The manual method 
is the most common, and especially recommended for the application of more complicated models in which a good graphical representation is a prerequisite (Refsgaard and Storm, 1990). In sediment transporting modeling a two steps calibration procedure has been suggested by (Neitsch et al., 2002), first check water balance contribution, then calibrate stream flow and followed by sediment calibration.

Calibrations of sediment yield were carried out at Abo Bahir. This site was selected due to the availability of measured sediment data.

In this study manual and automatic calibration methods were applied. First the parameters were automatically calibrated by using automatic calibration tool built in Arc SWAT and by using SWAT CUP until the model simulation result becomes acceptable as per the model performance measures. Then, the final parameter values that were calibrated using previous two calibration methods were used as the initial values for the manual calibration procedure.

The statistical and graphical approaches were also be used to evaluate the SWAT model performance a number of times until the acceptable values were obtained for sediment yield independently. SWAT developers in (Santhi et al., 2001) assumed an acceptable calibration for hydrology at $\mathrm{R}^{2}>0.6$ and NSE $>0.5$ and these values were considered in this study as a reference.

\subsubsection{Model validation}

Model validation is testing of calibrated model results with independent data set without any further adjustment at different spatial and temporal scales (Neitsch et al., 2002). In order to utilize the calibrated model for estimating the effectiveness of future potential management practices, the model tested against an independent set of measured data. Model calibration determines the best or at least a reasonable, parameter set while validation ensures that the calibrated parameters set performs reasonably well under an independent data set. Sediment validation was carried out at a station similar to the calibration for 6 years. The three statistical ( $\left.{ }^{2}, \mathrm{NSE} \& \mathrm{RSR}\right)$ and graphical model performance measures used in calibration procedure were also used in validating sediment yield.

\subsection{Model Performance Evaluation}

The evaluation of hydrologic model behavior and performance is commonly made and reported through comparisons of simulated and observed variables. Frequently, comparisons are made between simulated and measured stream flow at the catchment outlet. There are various methods to evaluate the model performance during the calibration and validation periods. Among those, the following performance evaluation criteria's were used in this study:

\section{Nash-Sutcliffe Efficiency}

The Nash-Sutcliffe efficiency (NSE) is a normalized statistic that determines the relative magnitude of the residual variance ("noise") compared to the measured data variance ("information"). NSE indicates how well the plot of observed versus simulated data fits the 1:1 line. NSE is computed using the following equation:

$$
N S E=1-\frac{\sum_{i=1}^{N}\left(\left(S_{i}-O_{i}\right)^{2}\right)}{\sum_{i=1}^{N}\left(\left(O_{i}-O_{\text {mean }}\right)^{2}\right)}
$$

Where $\mathrm{S}_{\mathrm{i}}=$ model simulated output; $\mathrm{O}_{\mathrm{i}}=$ observed hydrologic variable; $\mathrm{O}_{\text {mean }}=$ mean of the observations that the NSE uses as a benchmark against which performance of the hydrologic model is compared; and $\mathrm{N}=$ total number of observations. The value of NSE ranges from negative infinity to 1 (best. NSE value $<0$ indicates the mean observed value is better predictor than the simulated value, which indicates unacceptable performance. While NSE values greater than 0.5 , the simulated value is better predictor than mean measured value and generally viewed as acceptable performance (Santhi et al., 2001).

\section{Coefficient of Determination}

Coefficient of determination $\left(\mathrm{R}^{2}\right)$ is an indicator of the extent to which the model explains the total variance in the observed data. The $\mathrm{R}^{2}$ value is an indicator of strength of linear relationship between the observed and simulated values. $\mathrm{R}^{2}$ ranges from 0 (which indicates the model is poor) to 1 (which indicates the model is good), with higher values indicating less error variance, and typical values greater than 0.6 are considered acceptable (Santhi et al., 2001). The $\mathrm{R}^{2}$ is calculated using the following equation:

$$
R^{2}=\left(\frac{\sum_{i=1}^{N}\left(O_{i-} O_{\text {mean }}\right)\left(S_{i-} S_{\text {mean }}\right.}{\left(\sum_{i=1}^{N}\left(O_{i-} O_{\text {mean }}\right)^{2}\right)^{0.5}\left(\sum_{i=1}^{N}\left(S_{i-} S_{\text {mean }}\right)^{2}\right)^{0.5}}\right)^{2}
$$

Where, $\mathrm{S}_{\text {mean }}=$ mean of the model simulations

A major limitation of $\mathrm{R}^{2}$ is that it describes the linear relationship between the two data sets, and one may obtain large $\mathrm{R}^{2}$ value with a poor model that consistently overestimates or underestimates the observations.

\section{Root Mean Square Error}

$$
R M S E=\sqrt{\frac{1}{N}} \sum_{i=1}^{N}\left(S_{i}-O_{i}\right)^{2}
$$


RMSE ranges from zero (ideal model) to positive infinity (worst model). RMSE is biased toward peak flows. Simulations are judged as satisfactory if NSE $\geq 0.5$, RSR $\leq 0.70$ and $\mathrm{R}^{2} \geq 0.6$ for flow and sediment (Moriasi et al., 2007)

\section{Results and Discussion}

\subsection{Land Use and Land Cover Change Analysis}

\subsubsection{Land Use and Land Cover Maps}

Classification of the 1973 land sat satellite image gives that bush/ shrub land with a value of $65.501 \%$, cultivated land with $22.9933 \%$, grazing and forest lands with , 6.851\% and 4.259\% coverage's respectively (Figure 4.1 and Table 4.1 ). Urban and water covers small percentages, i.e $0.316 \%$ and $0.080 \%$ respectively.

The classification of 1995 land sat satellite image in Upper Ribb Watershed (Figure 4.2 and Table 4.1) revealed that the proportion of land allocated for cultivation expanded to $55.405 \%$. And also, grazing land, urban area and water body have increased to $28.405 \%, 0.537 \%$ and $0.36 \%$ respectively. However, the proportions of bush/shrub land and forest cover have decreased to $13.516 \%$ and $1.775 \%$ respectively.

The 2016 land sat satellite image classification showed that the land cover classes (Figure 4.3 and Table 4.1) were also dominated by cultivated lands with $52.940 \%$, followed by the ever increasing bush/shrub land with $31.306 \%$ and the ever decreasing grazing and forest cover with $10.297 \%$ and $1.570 \%$ respectively.

Other land cover classes also covered with woody savanna grassland $2.069 \%$, urban and settlement area $1.406 \%$ and water body $0.412 \%$.

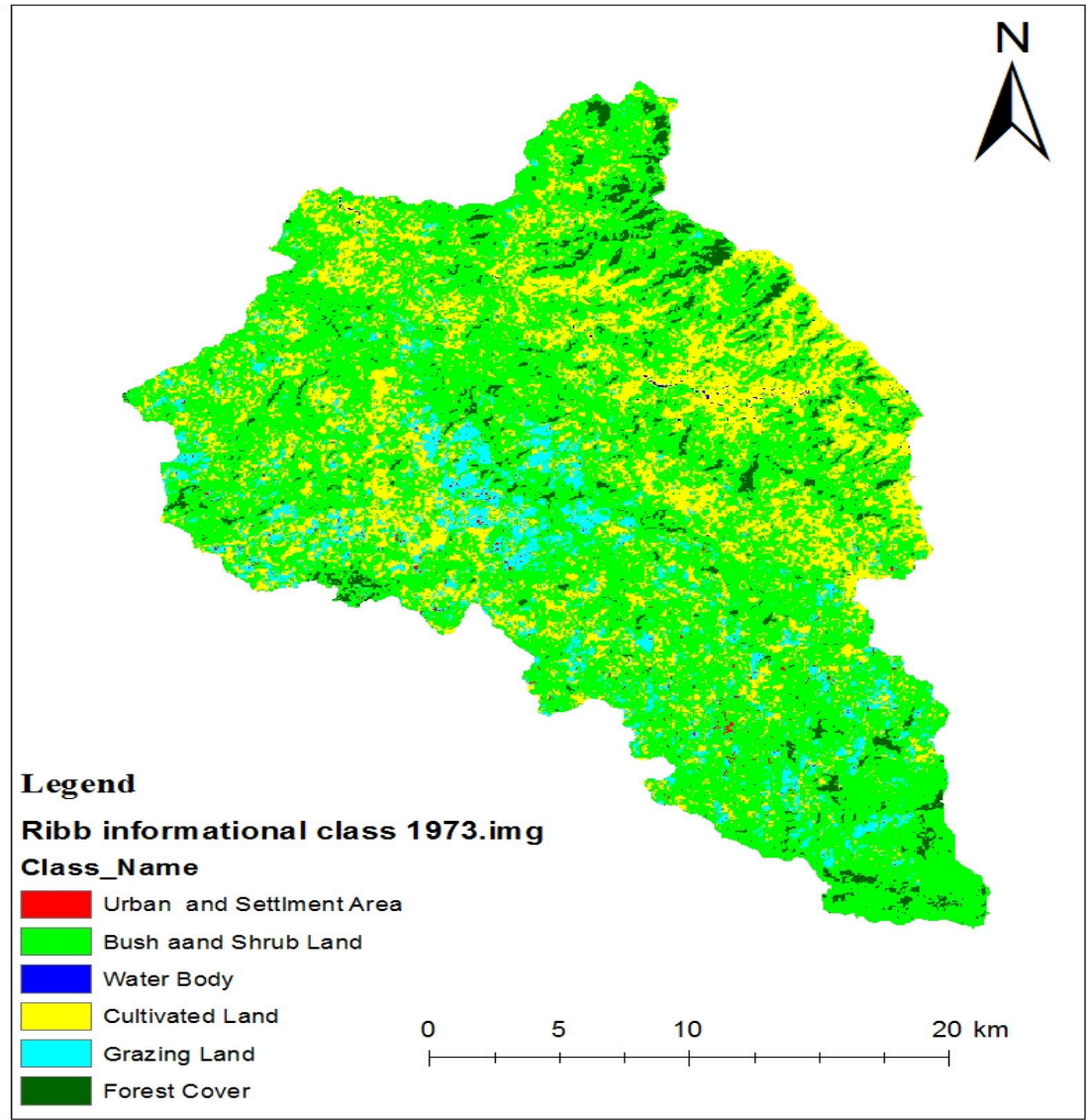

Figure 4. 1 Land use and land cover map of Upper Ribb Watershed in 1973 
Legend

Ribb informational class 1995.img

Class_Name

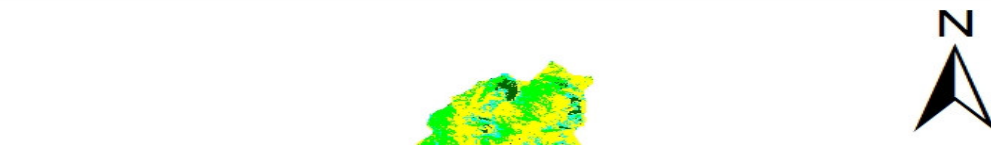

Urban and Settument Area

Forest cover

Grasing Land

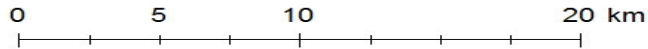

Cultivated Land

Figure 4. 2 Land use and land cover map of Upper Ribb Watershed in 1995

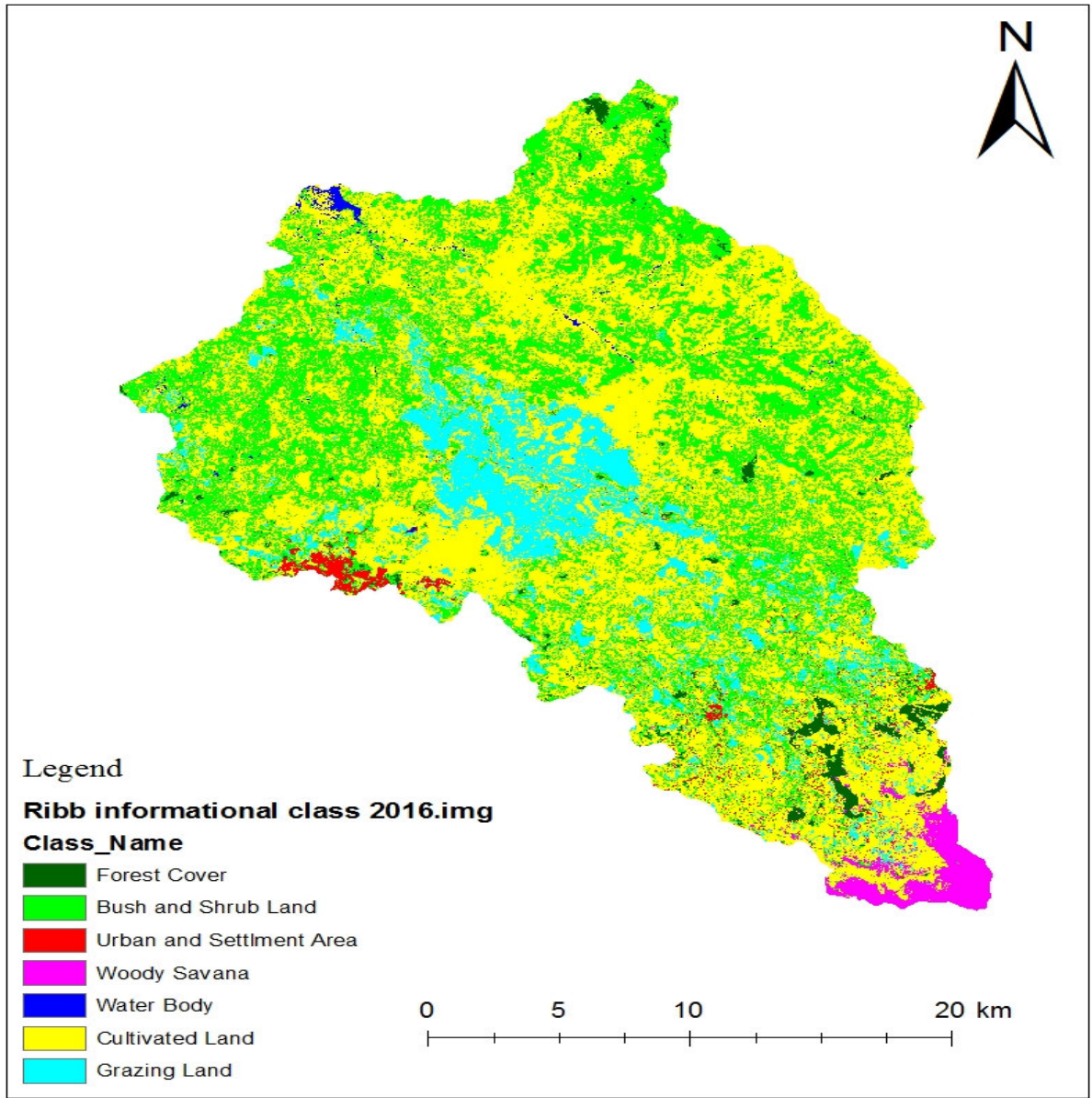

Figure 4. 3 Land Use and land cover map of Upper Ribb Watershed in 2016 
Table 4. 1 Summary of land use/cover change percentage of Upper Ribb Watershed

\begin{tabular}{|l|l|l|l|l|l|l|}
\hline \multirow{2}{*}{$\begin{array}{l}\text { Land cover } \\
\text { classes }\end{array}$} & \multicolumn{2}{l}{ Years } & \multicolumn{2}{l|}{ Land use change detection } \\
\cline { 2 - 7 } & 1973 & 1995 & 2016 & $1973-1995$ & $1995-2016$ & $1973-2016$ \\
\hline Cultivated Land & 22.993 & 55.405 & 52.940 & +32.412 & -2.464 & +29.947 \\
\hline Grazing Land & 6.851 & 28.405 & 10.297 & +21.554 & -18.107 & +3.446 \\
\hline Bush and Shrub Land & 65.501 & 13.516 & 31.306 & -51.985 & +17.790 & -34.195 \\
\hline Forest Cover & 4.259 & 1.775 & 1.570 & -2.485 & -0.205 & -2.690 \\
\hline Water Body & 0.080 & 0.363 & 0.412 & +0.283 & +0.049 & +0.331 \\
\hline Urban and Settlement Area & 0.316 & 0.537 & 1.406 & +0.221 & +0.869 & +1.090 \\
\hline Woody Savanna Land & & & 2.069 & & & +2.069 \\
\hline
\end{tabular}

The above result (Table 4.1) shows that there was a dramatic increase of cultivated and grazing lands for the first period $(1973-1995)$ with +32.412 and +21.554 respectively. Conversely bush/shrub lands were decreased by $51.985 \%$ for this period. However, the bush/shrub lands show appreciable increase during the second period $(1995-2016)$ with $+17.790 \%$. On the contrary, the grazing land showed a significant decrease in the second period (1995 - 2016) with $18.107 \%$.

Previous similar studies in this watershed and other parts of the country also reflect similar results. For instance, (Garede and Minale, 2014) showed the cultivated \& settlement land, shrub land and grassland coverage during 2011 were $70.43 \%, 14 \%$ and $7.58 \%$ respectively for the whole Ribb catchment in the north western part of Ethiopia. (Yeshaneh et al., 2013) stated that crop field coverage in Koga watershed in 2010 were $76.83 \%$.

(Geremew, 2013) shows that the cultivated area was increased by $45 \%$, while forest, grassland, shrub land and water was decreased by $2 \%, 34 \%, 5.7 \%$ and $4.9 \%$ respectively from 1986 to 2001 .

(Hadgu, 2008) indicating a sharp reduction of natural habitats and an increase in agricultural land in the highlands of Tigray, northern Ethiopia over a period of 41 years $(1964-2005)$. He reported that shrub land was dominant in 1964 covering $46 \%$ of the area followed by woodland with coverage of $28 \%$ of the area. However, agricultural land was dominant in both 1994 and 2005 covering 34\% and 40\% respectively. The next dominant LULC types in 1994 and 2005 were shrub land with coverage of $21 \%$ and $39 \%$.

(Andualem and Gebremariam, 2015) reported that there was an increase of cultivated lands and a decrease of forest cover by 33.79 and 1.4 percent respectively in Gilgel Abbay watershed, north western Ethiopia from the periods $1986-2011$.

(Bewket, 2003) identifies agricultural conversion of $79 \%$ of the Riverine forests of the Chemoga watershed within the Blue Nile basin from 1957 to 1998. (Rientjes et al., 2011) also presented the agricultural land, shrub land and grassland coverage during 2001 were $62.7 \%, 8.9 \%$ and $8.8 \%$ respectively for Upper Gilgel Abay catchment.

\subsubsection{Accuracy Assessment}

An accuracy assessment was made by using a confusion matrix with 200 randomly selected points (Table 4.2) by using land use maps, ground truth points and Google Earth. Great importance was given to the representation of different LU/LC classes by these randomly chosen points.

Table 4. 2 Confusion matrixes for the classification of 2016 land use

\begin{tabular}{|c|c|c|c|c|c|c|c|c|c|}
\hline \multirow{2}{*}{$\begin{array}{l}\text { Classified } \\
\text { Image }\end{array}$} & \multicolumn{8}{|c|}{ Ground Truth } & \multirow[b]{2}{*}{$\begin{array}{l}\text { User's } \\
\text { Accuracy }\end{array}$} \\
\hline & Cultivated & Bush & Grazing & Forest & Urban & Water & Woody & Total & \\
\hline Cultivated & 101 & 0 & 2 & 0 & 0 & 0 & 0 & 103 & $98.06 \%$ \\
\hline Bush & 2 & 31 & 2 & 1 & 0 & 0 & 0 & 36 & $86.11 \%$ \\
\hline Grazing & 1 & 1 & 46 & 0 & 0 & 0 & 0 & 48 & $95.83 \%$ \\
\hline Forest & 0 & 0 & 1 & 6 & 0 & 0 & 0 & 7 & $85.71 \%$ \\
\hline Urban & 0 & 0 & 0 & 0 & 1 & 0 & 0 & 1 & $100 \%$ \\
\hline Water & 0 & 0 & 0 & 0 & 0 & 1 & 0 & 1 & $100 \%$ \\
\hline Woody & 0 & 0 & 0 & 0 & 0 & 0 & 4 & 4 & $100 \%$ \\
\hline Total & 104 & 32 & 51 & 7 & 1 & 1 & 4 & 200 & \\
\hline $\begin{array}{l}\text { Producer' } \\
\text { s accuracy }\end{array}$ & $97.12 \%$ & $96.88 \%$ & $90.20 \%$ & $85.71 \%$ & $100 \%$ & $100 \%$ & $100 \%$ & $\begin{array}{l}\text { Overal } \\
=96 \%\end{array}$ & Accuracy \\
\hline
\end{tabular}

The 2016 land use and land cover classification has showed, user's accuracy and producer's accuracy are greater than $85 \%$, as well the overall accuracy of $96 \%$ (Table 4.2). These values indicate the land sat and the methodologies used were so accurate. The Kappa coefficient also calculated, with a value of $\mathrm{K}=0.92$ which indicated the classification is almost perfect since it is between 0.81 and 1.00 (Landis and Koch, 1977). 


\subsection{Sediment yield modeling}

Sensitivity analysis of simulated sediment yield for the Upper Ribb Watershed was performed using the monthly observed sediment yield for identifying the most sensitive parameter and for further calibration and validation of the simulation of sediment yield. The monthly observed sediment yield was developed from a simple linear regression sediment rating curve at Abo Bahir $\left(1166 \mathrm{~km}^{2}\right)$. At this site suspended sediment concentration was measured and rating curves were developed from 2012 to 2013(Lemma et al., 2017). They develop those curves by subdivided the datasets into five periods (i.e. October- April, May - June, July, August and September) based on changes in rainfall, soil moisture and land-cover conditions.

Based on those rating equations the monthly suspended sediment loads were estimated. During sensitivity analysis of sediment six sediment parameters were checked for sensitivity and sensitive parameters were identified. From those parameters the first three (Ch_cov, Ch_Erod and USLE_P) were highly sensitive and given to high priority for calibration (Table 4.3).

Table 4. 3 Sensitive sediment flow parameters

\begin{tabular}{|c|c|c|c|c|c|}
\hline \multicolumn{3}{|c|}{ Parameters } & \multirow[t]{2}{*}{ Rank } & \multirow{2}{*}{$\begin{array}{l}\text { Calibrated } \\
\text { value }\end{array}$} & \multirow[t]{2}{*}{ Significance } \\
\hline Name & Description & $\begin{array}{l}\text { Value } \\
\text { range }\end{array}$ & & & \\
\hline Ch_Cov & Channel cover factor & $0-1$ & 1 & 0.739 & high \\
\hline Ch_Erod & Channel erodibility factor & $0-1$ & 2 & 0.443 & high \\
\hline USLE P & USLE support practice factor & $0-1$ & 3 & 0.427 & high \\
\hline USLE_C & Minimum USLE cover factor & $0-1$ & 4 & 0.695 & Low \\
\hline Spcon & $\begin{array}{l}\begin{array}{l}\text { Linear parameter for channel sediment } \\
\text { routing }\end{array} \\
\end{array}$ & $0.0001-0.01$ & 5 & 0.0025 & Low \\
\hline Spexp & $\begin{array}{l}\text { Exponential factor for channel sediment } \\
\text { routing }\end{array}$ & $1-2$ & 6 & 1.837 & Low \\
\hline
\end{tabular}

The SWAT calibration and validation for the sediment load was conducted after the model was calibrated and validated for the stream flow using sensitive and significant sediment parameters identified (Table 4.3). The simulated sediment flow results were calibrated firstly using SUFI and then by using manual calibration. This was done by simulating the sediment for eight years period (1982 - 1989) for calibration and nine years period (1996 - 2002) for validation including one year warm period for each. These periods were selected since the observed flow data used for developing suspended sediment loads did not have any missing value. The performances of the calibrated and validated simulations were also checked by NSE, $\mathrm{R}^{2}$ and RSR.

The SWAT model was found to simulate well on monthly basis of sediment load. Coefficient of determination $\left(\mathrm{R}^{2}\right)$ value and Nash-Sutcliffe model efficiency (NSE) statistic computed between the simulated and observed monthly sediment loads of 1995 land use for the calibration periods were 0.857 and 0.832 respectively. It also gives Coefficient of determination $\left(\mathrm{R}^{2}\right)$ ) and Nash-Sutcliffe model efficiency (NSE) values of 0.834 and 0.796 respectively for the validation periods.

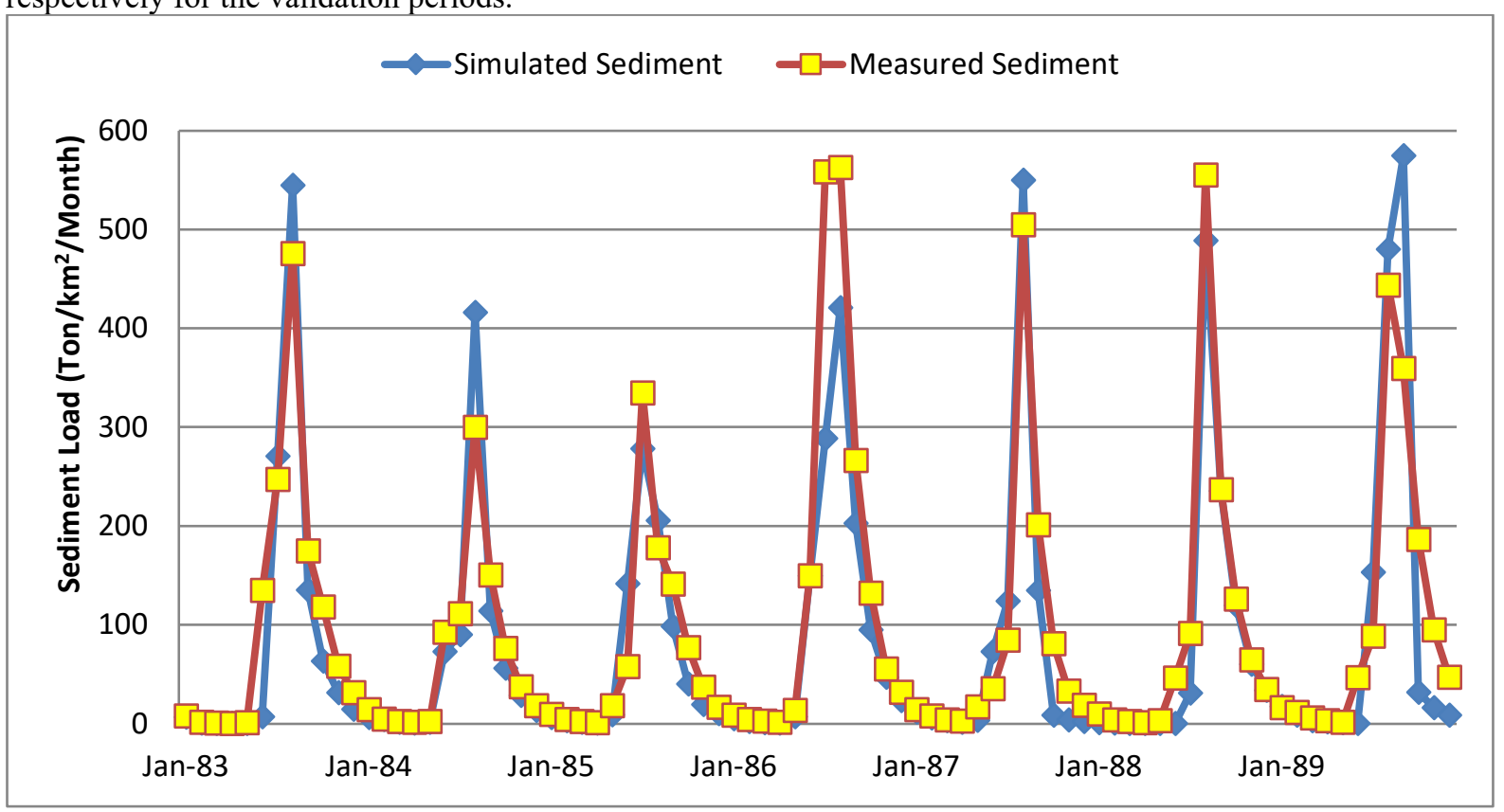

Figure 4. 4 Monthly calibrated sediment load from 1983 - 1989 for 1995 land use 


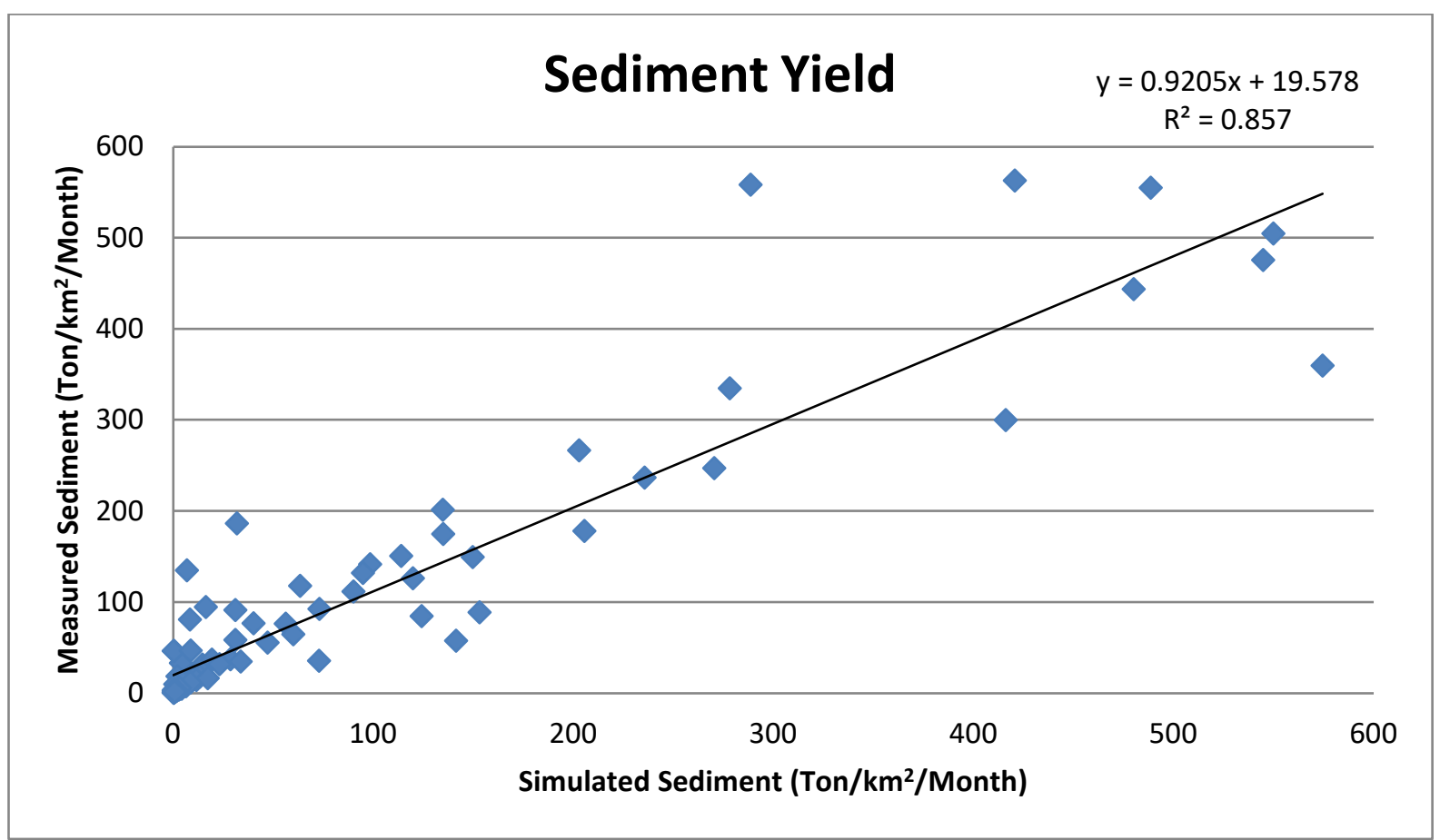

Figure 4. 5 1:1 fit line of measured and simulated load of 1995 land use for Calibration

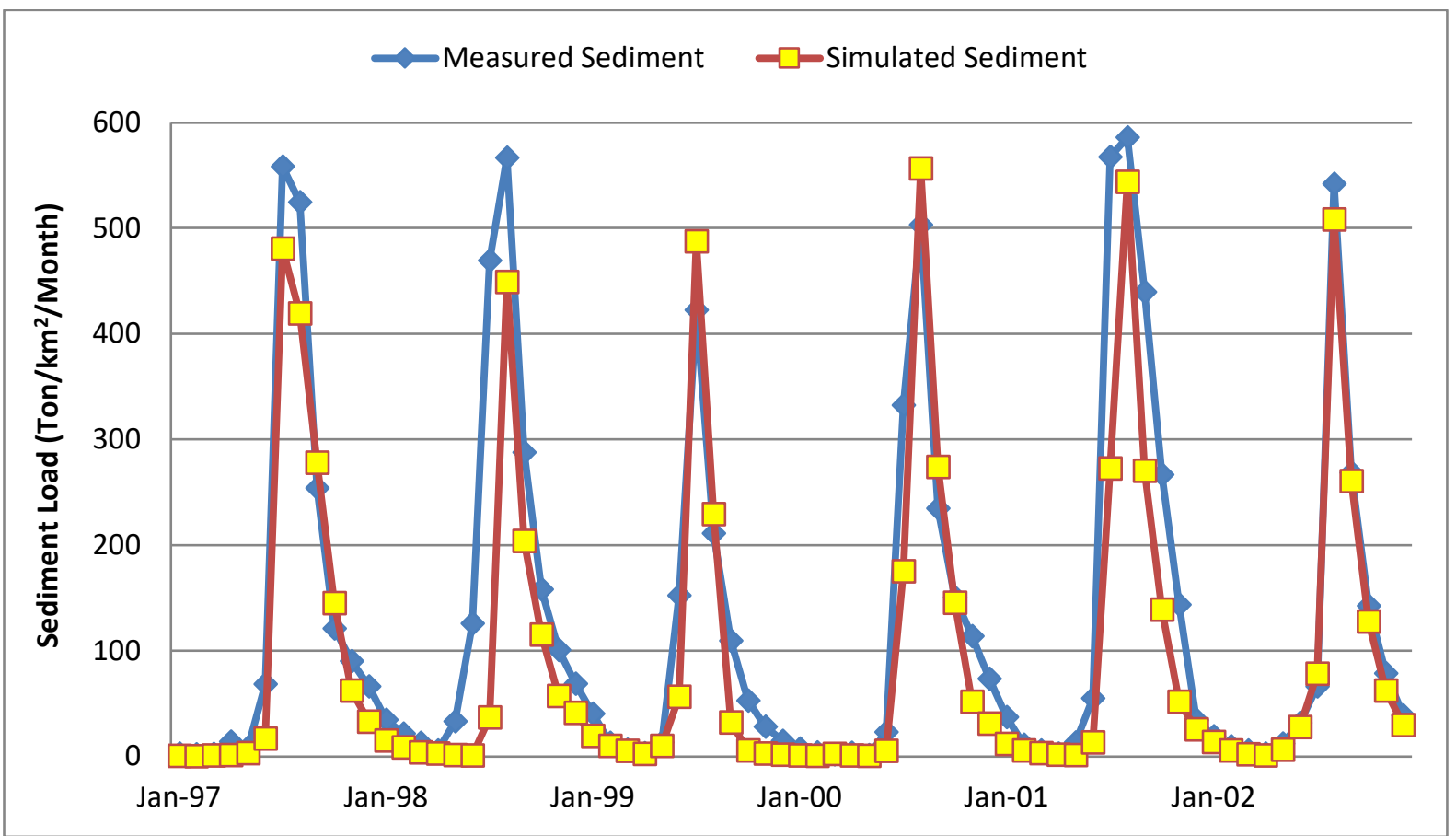

Figure 4. 6 Monthly Validated sediment load from 1997 - 2002 for 1995 land use 


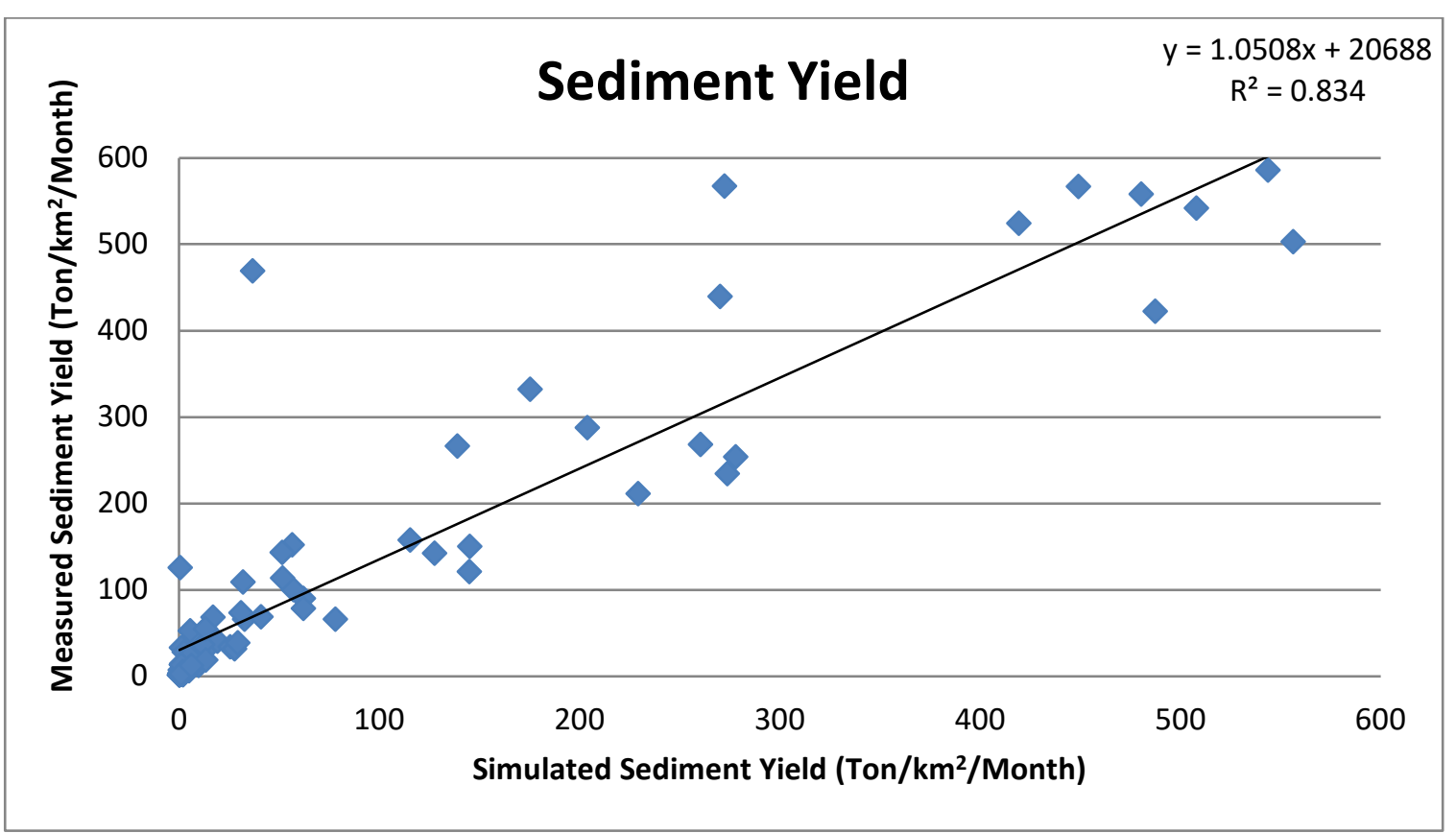

Figure 4. 7 1:1 fit line of measured and simulated load of 1995 land use for Validation

Table 4. 4 Comparison of measured and simulated monthly sediment load for calibration and validation simulations of 1995 land use

\begin{tabular}{|c|c|c|c|c|c|}
\hline \multirow[t]{2}{*}{ Period } & \multicolumn{2}{|c|}{ sediment load (ton $\left./ \mathrm{km}^{2} / \mathrm{month}\right)$} & \multirow[t]{2}{*}{ NSE } & \multirow[t]{2}{*}{$\mathrm{R}^{2}$} & \multirow[t]{2}{*}{ RSR } \\
\hline & Measured & Simulated & & & \\
\hline $\begin{array}{l}\text { Calibration Period } \\
(1983-1989)\end{array}$ & 88.684 & 83.436 & 0.832 & 0.857 & 0.043 \\
\hline $\begin{array}{l}\text { Validation Period } \\
(1997-2002)\end{array}$ & 86.452 & 82.207 & 0.796 & 0.834 & 0.046 \\
\hline
\end{tabular}

The sediment calibration and validation results displayed less than five percent difference between the simulated and measured monthly sediment load. These result shows that model performance is good with simulation of monthly sediment load.

Similar studies in other areas also support the findings of this study. (Andualem and Gebremariam, 2015) in there study of sediment yield at Gilgel Abay watershed has showed a good value of $\mathrm{R}^{2}(0.87$ to 0.92$)$ and NSE ( 0.75 to 0.79$)$. (Setegn, 2008) has reported that simulation of sediment for Anjeni watershed reveals good correlation and agreement with the observed sediment, with the values of $\mathrm{R}^{2}(0.85)$ and NSE (0.81) for the calibration period. Through assessment of reservoir sedimentation at Karadobi (DEREJE, 2010) reflects acceptable ranges of $\mathrm{R}^{2}(0.80$ to 0.95$)$ and $\mathrm{NSE}(0.72$ to 0.92$)$.

\subsection{Evaluation of sediment yield due to land use and land cover change}

The main important objective of this study was to estimate effect of the land use and land cover change on the sediment yield at the Ribb dam outlet or at the reservoir. Thus, these effects of the watershed were evaluated using the calibrated sediment parameters, which were identified at Abo Bahir site for the three different land cover changes.

Table 4. 5 Sediment yield (t/km2/year) results of Upper Ribb Watershed due to land use/cover change

\begin{tabular}{|c|c|c|c|c|c|}
\hline \multicolumn{3}{|c|}{ Years } & \multicolumn{3}{c|}{ Change detection } \\
\hline Simulated & 1995 & 2016 & & \multicolumn{3}{|c|}{ Simulated } & Simulated & $1973-1995$ & $1995-2016$ & $1973-2016$ \\
\hline 290.05 & 781.3 & 633.3 & 491.25 & -148 & 343.25 \\
\hline
\end{tabular}

The annual sediment yield of Upper Ribb Watershed highly increased in the first period due to high amount of land use changes into over grazing and cultivated area. The sediment yield results for the different years were compared based on the calibrated and validated average values.

An increase of sediment yield by $491.25 \mathrm{t} / \mathrm{km}^{2} /$ year $(1973-1995)$ was due to an increase of cultivated area by $32.412 \%$ and grazing land by $21.554 \%$ (Table 4.1 ), and also a decrease of sediment yield by $148 \mathrm{t} / \mathrm{km}^{2} / \mathrm{year}$ (1995 - 2016) was due to a decrease of over grazing land by $18.107 \%$ and an increase of bush/shrub lands by $17.790 \%$. Other reasons can be because of the fact that recent conservation activities were taken in the area for watershed management. 
Generally speaking, the net sediment yield has increased throughout the study period for over 43 years period with a magnitude of $343.25 \mathrm{t} / \mathrm{km}^{2} /$ year $(1973-2016)$. These tremendous changes of sediment yield were due to the land cover changes of the watershed (an increase of cultivated land trough study period by $29.947 \%$ ). These indicated that land use change has a significant effect on sediment yield of Upper Ribb watershed.

Similar studies in the area and in Blue Nile Basin also support the results of this study. In this area for example, (Reclamation, 1964) reported that the sediment yield estimated for the Ribb dam site was 363 ton $/ \mathrm{km}^{2} /$ year. BCEOM (1999) also estimate the annual sediment yield at this site and obtained a value of 675 ton $/ \mathrm{km}^{2}$. For Blue Nile Basin, (DEREJE, 2010) reported that the sediment yields at Kessie and Karadobi were 898 ton $/ \mathrm{km}^{2} /$ year and $855 \mathrm{ton} / \mathrm{km}^{2} /$ year respectively. Thus, in this study when we compare these values with the model output it is possible to conclude that SWAT has well estimated the sediment yield at the Ribb dam outlet for the three different land use changes.

\subsection{Spatial Sediment Distribution}

Identifying the most erosion hotspot areas (sub-watersheds) in the watershed is very necessary to give prior attention and proper management or watershed development for local governments and other stakeholders. Spatial variability of sediment yield from Upper Ribb watershed was identified from the calibrated sediment outputs for each of the sub-basins. The average annual yield of sediment transport out of reach in metric tons for each subbasin was used to generate the sediment source map.

The soil loss and severity class in the basin were classified as light $(0-15 \mathrm{t} / \mathrm{ha} / \mathrm{yr})$, moderate $(15-50 \mathrm{t} / \mathrm{ha} / \mathrm{yr})$, intensive (50-80t/ha/yr), utterly intensive (80-150t/ha/yr) and severe ( $>150$ t/ha/yr), (Piest et al., 1975).

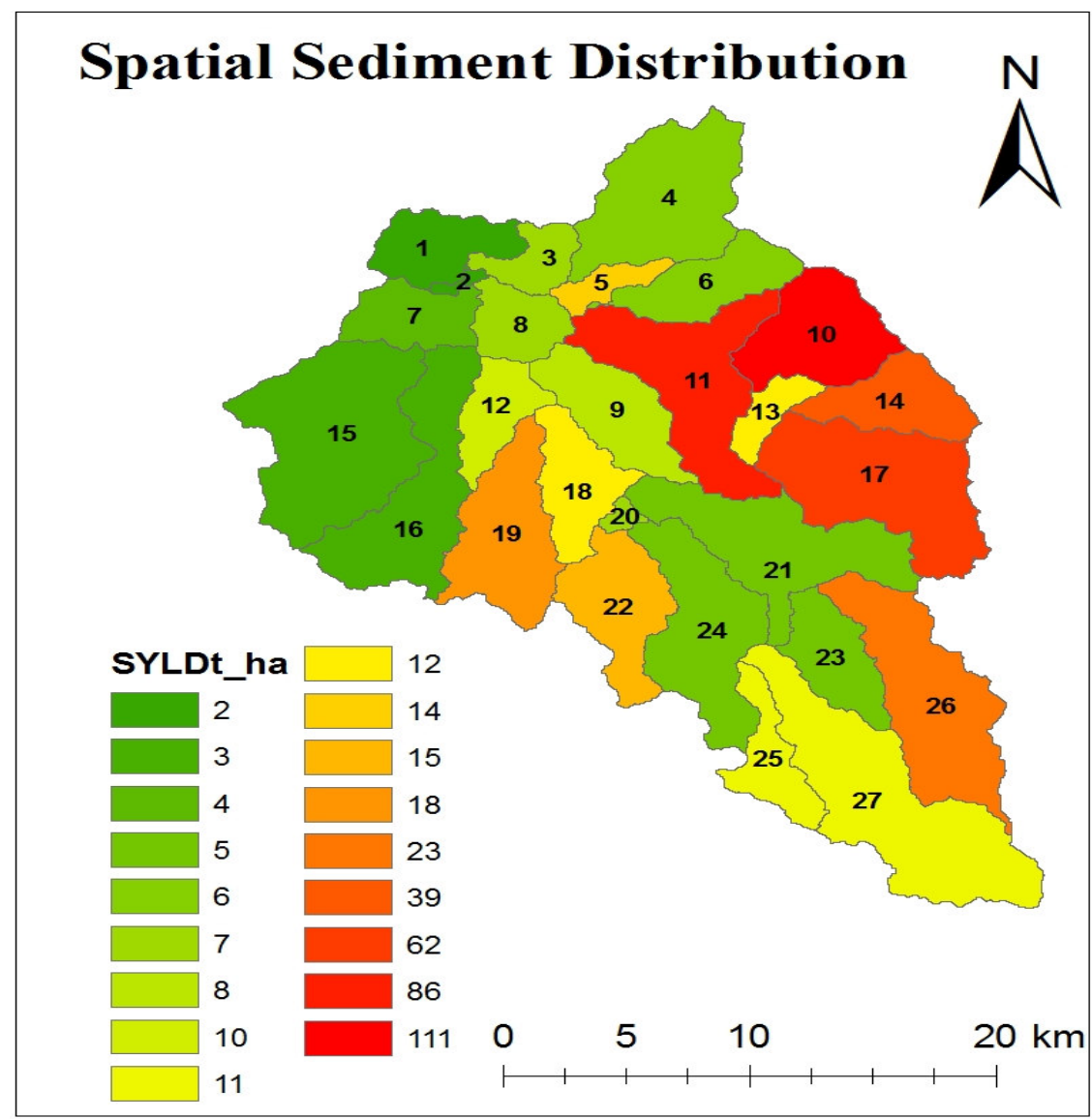

Figure 4. 8 Spatial variability of sediment yield (t/ha/yr) in Upper Ribb Watershed

The result of the SWAT output (Figure 4.8) indicated that sub-watersheds 10, 11 and 17 are high, subwatersheds 14, 26, 19 and 22 were moderate potential source area for sediment, and on the other hand sub-basin 16, 15, 2 and 1 were very low potential source area for sediment having less than $3.5 \mathrm{t} / \mathrm{ha} / \mathrm{yr}$. Sub watersheds which are known to be highly cultivated area are more vulnerable to soil erosion. And also Sub watersheds at a higher slope condition have shown higher contribution of sediment yield. Therefore, in this study Sub watersheds in the north eastern part were highly erosive due to steep slope, intensive cultivation and erosive soil (Eutric Leptosols). In fact when it compared with the spatial sediment distribution output of the 1995 land use and land cover it decreases appreciably. This was due to recent conservation activities taken in the area for watershed management mainly through increasing/expanding bush and shrub lands. Hence, such like works should be 
continued to preserve the watershed first by applying for those most erosion prone sub watersheds.

Finally the identification of the most erosion prone Sub watersheds will help the local government and other stakeholders who are interested and involved in successfully plan and implement appropriate watershed management activities particularly to protect the Ribb dam from the reservoir siltation.

\section{Conclusions}

This study has addressed the impact of land use/ cover changes on Ribb Dam reservoir sedimentation using SWAT model. The study shows that Upper Ribb watershed has experienced a significant change in land use and land cover over the past 43 years.

The sensitivity analysis using SWAT model has resulted three important parameters that control the sediment yield of the studied watershed. In the sediment yield calibration, Channel cover factor (Ch_Cov), Channel erodibility factor (Ch_Erod) and USLE support practice factor (USLE_P) were found to be the most sensitive parameters and were adjusted automatically and manually till the simulation is good fit to the measured sediment yield. On the other hand, model calibration and validation have showed that the SWAT model simulated the sediment load quit satisfactorily. Performance efficiency indicators show that the SWAT model simulates well both for sediment yield in the Upper Ribb Watershed. Thus, the Nash-Sutcliffe model efficiency (NSE) and coefficient of determination $\left(\mathrm{R}^{2}\right)$ are found to be 0.832 and 0.857 in calibration and 0.796 and 0.834 in validation for sediment yield analysis.

After calibration and validation of the model, impacts of the land use and land cover change on sediment yield was carried out. The changes in land use has resulted changes in sediment yield, in which the expansion of cultivated lands results an increase of sediment yield. Over 43 years period $(1973-2016)$ an increase of cultivated land by $29.947 \%$ resulted in an increase of sediment yield by $343.25 \mathrm{t} / \mathrm{km}^{2}$.

To sum up sediment yield has showed a direct relationship with cultivated land as a result they increased from year to year.

The spatial variability of sediment source areas were identified and mapped using GIS. As a result sub watersheds of 10,11 and 17 were identified as more potential sediment source areas (highly erodible) due to steep slope, intensive cultivation and erosive soil (Eutric Leptosols). Those sub watersheds indicated that, it requires prior attention for appropriate watershed management practices in the watershed.

Sedimentation of reservoirs, erosion of agricultural soil, degradation of cultivable and potential areas are the major problem in Ethiopia particularly in the highlands for many years and will continue in the future except appropriate watershed management activities are taken. This is due to the topography of the watershed, high densely population and poor management practices taken in the watershed. To manage this problem, among those factors only one i.e. impact of land use and land cover changes on reservoir sedimentation was considered in this work so as to contribute something in problem solving in this watershed. Thus, to protect the Ribb dam from the reservoir siltation the local government and other stakeholders should implement appropriate watershed management activities by giving prior attention for those identified erosion prone Sub watersheds. This will done by; first forest resources development, protection and use strategies need to be devised to encourage the increasing/expanding bushes/shrub land, which reduces the annual sediment inter into the reservoir. Second as detected in this study high potential source areas are shown on those have cultivated with steep slopes. Therefore it is preferred such area uncultivated rather cover with plantations.

\section{REFERENCES}

ANDUALEM, T. G. \& GEBREMARIAM, B. 2015. Impact Of Land Use Land Cover Change On Stream Flow And Sediment Yield: A Case Study Of Gilgel Abay Watershed, Lake Tana Sub-Basin, Ethiopia. Arba Minch University.

ASRES, M. T. \& AWULACHEW, S. B. 2010. SWAT based runoff and sediment yield modelling: a case study of the Gumera watershed in the Blue Nile basin. Ecohydrology \& Hydrobiology, 10, 191-199.

BEWKET, W. 2003. Towards integrated watershed management in highland Ethiopia: the Chemoga watershed case study.

CAMPBELL, W. \& MORTENSON, D. 1989. Ensuring the quality of geographic information system data: a practical application of quality control.

DEREJE, D. H. 2010. Impact of land use change on reservoir sedimentation (case study of karadobi).

DROOGERS, P. \& KITE, G. 2001. Estimating productivity of water at different spatial scales using simulation modeling, IWMI.

EMADODIN, I., REISS, S. \& BORK, H. R. 2009. A study of the relationship between land management and soil aggregate stability (case study near Albersdorf, Northern-Germany). Journal of Agriculture and Biological Sciences, 4, 48-53.

GAREDE, N. \& MINALE, A. 2014. Land Use/Cover Dynamics in Ribb Watershed, North Western Ethiopia. $J$. Nat. Sci. Res, 4, 16. 
GEREMEW, A. A. 2013. Assessing the impacts of land use and land cover change on hydrology of watershed: a case study on Gigel-Abbay Watershed, Lake Tana Basin, Ethiopia.

GUO, H., HU, Q. \& JIANG, T. 2008. Annual and seasonal streamflow responses to climate and land-cover changes in the Poyang Lake basin, China. Journal of Hydrology, 355, 106-122.

HADGU, K. M. 2008. Temporal and spatial changes in land use patterns and biodiversity in relation to farm productivity at multiple scales in Tigray, Ethiopia.

HURNI, H., ABATE, S., BANTIDER, A., DEBELE, B., LUDI, E., PORTNER, B., YITAFERU, B. \& ZELEKE, G. 2010. Land degradation and sustainable land management in the highlands of Ethiopia.

LANDIS, J. R. \& KOCH, G. G. 1977. The measurement of observer agreement for categorical data. biometrics, 159-174.

LEMMA, H., ADMASU, T., DESSIE, M., FENTIE, D., DECKERS, J., FRANKL, A., POESEN, J., ADGO, E. \& NYSSEN, J. 2017. Revisiting lake sediment budgets: how the calculation of lake lifetime is strongly data and method dependent. Earth Surface Processes \& Landforms.

LENHART, T., ECKHARDT, K., FOHRER, N. \& FREDE, H.-G. 2002. Comparison of two different approaches of sensitivity analysis. Physics and Chemistry of the Earth, Parts $A / B / C, 27,645-654$.

MANANDHAR, R., ODEH, I. \& ANCEV, T. 2009a. Improving the accuracy of land use and land cover classification of Landsat data using post-classification enhancement. Remote Sensing, 1, 330-344.

MANANDHAR, R., ODEH, I. O. \& ANCEV, T. 2009b. Improving the accuracy of land use and land cover classification of Landsat data using post-classification enhancement. Remote Sensing, 1, 330-344.

MORIASI, D. N., ARNOLD, J. G., VAN LIEW, M. W., BINGNER, R. L., HARMEL, R. D. \& VEITH, T. L. 2007. Model evaluation guidelines for systematic quantification of accuracy in watershed simulations. Transactions of the ASABE, 50, 885-900.

NEITSCH, S., ARNOLD, J., KINIRY, J., SRINIVASAN, R. \& WILLIAMS, J. 2002. Soil and Water Assessment Tool User's Manual: Version 2000. GSWRL Report 02-02, BRC Report 02-06, Publ. Texas Water Resources Institute. TR-192, College Station, Texas.

PIEST, R., BRADFORD, J. \& SPOMER, R. 1975. Mechanisms of erosion and sediment movement from gullies. Present and prospective technology for predicting sediment yields and sources, 162-176.

RECLAMATION, U. S. B. O. 1964. Land and Water Resources of the Blue Nile Basin, Ethiopia.

REFSGAARD, J. C. \& STORM, B. 1990. Construction, calibration and validation of hydrological models. Distributed hydrological modelling. Springer.

RIENTJES, T., HAILE, A., KEBEDE, E., MANNAERTS, C., HABIB, E. \& STEENHUIS, T. 2011. Changes in land cover, rainfall and stream flow in Upper Gilgel Abbay catchment, Blue Nile basin-Ethiopia. Hydrology and Earth System Sciences, 15, 1979.

SANTHI, C., ARNOLD, J. G., WILliAMS, J. R., DUGAS, W. A., SRINIVASAN, R. \& HAUCK, L. M. 2001. Validation of the swat model on a large rwer basin with point and nonpoint sources. JAWRA Journal of the American Water Resources Association, 37, 1169-1188.

SETEGN, S. G. 2008. Hydrological and sediment yield modelling in Lake Tana basin, Blue Nile Ethiopia. KTH.

SETEGN, S. G., SRINIVASAN, R. \& DARGAHI, B. 2008. Hydrological modelling in the Lake Tana Basin, Ethiopia using SWAT model. The Open Hydrology Journal, 2.

SURUR, A. 2010. Simulated Impact of Land Use Dynamics on Hydrology during a 20-year-period of Beles Basin in Ethiopia.

WHITE, K. L. \& CHAUBEY, I. 2005. Sensitivity analysis, calibration, and validations for a multisite and multivariable SWAT model. JAWRA Journal of the American Water Resources Association, 41, 1077-1089.

YESHANEH, E., WAGNER, W., EXNER-KITTRIDGE, M., LEGESSE, D. \& BLÖSCHL, G. 2013. Identifying land use/cover dynamics in the Koga catchment, Ethiopia, from multi-scale data, and implications for environmental change. ISPRS International Journal of Geo-Information, 2, 302-323.

ZIMAle, F. A., MOGES, M. A., AlEMU, M. L., AYANA, E. K., DEMISSIE, S. S., TILAHUN, S. A. \& STEENHUIS, T. S. 2016. Calculating the sediment budget of a tropical lake in the Blue Nile basin: Lake Tana. SOIL Discussions, 1-32. 